\title{
Solasaldi Literarioak Haur Hezkuntzan: Donostiako ikastola batean burututako esperientzia
}

\author{
Literary Discussion groups in Pre-School Education: an experience carried \\ out at in an ikastola in Donostia
}

\author{
Goiatz Aramendi Lekuona, Pello Aramendi Jauregi* \\ Hezkuntza, Filosofia eta Antropologia Fakultatea
}

$\mathrm{UPV} / \mathrm{EHU}$

\begin{abstract}
LABURPENA: Literatura unibertsalaren lanik onenak partekatzeko, elkarrizketan eta gozamenean oinarritutako hezkuntza-jarduera arrakastatsuenetako bat da solasaldi literarioa. Ikerketaren helburu orokorra da solasaldi literarioak, Oinarrizko Zeharkako Konpetentziak eta Esperientzia Eremuak, Haur Hezkuntzan garatzeko egokiak diren frogatzea. Esperientzia hau Donostiako ikastola batean landu da eta bost urteko 21 ikaslek (15 neska eta 6 mutil) parte hartu dute. Lau ipuinen solasaldiak aztertu ondoren, argi ikusten da solasaldi literarioak, estrategia metodologiko gisa, oso egokiak direla Haur Hezkuntzako Esperientzia Eremuak eta Zeharkako Oinarrizko Konpetentziak lantzeko. Gehien lantzen diren konpetentziak komunikazioa, elkarbizitza eta izaten ikastea dira. Ikasten ikasi eta ekiten ikasi konpetentziak, aldiz, askoz ere gutxiago lantzen dira. Lan honetan ondorioztatzen dena honako hau da: solasaldi literarioan irakaslearen rolak duen garrantzia, konpetentziak eta esperientzia eremuak garatzeko; kontuan izanik, hezitzailearen zeregin nagusia ikaslearen garapen osoa lortzea dela.
\end{abstract}

GAKO HITZAK: Solasaldi literarioak, Haur Hezkuntza, Irakurzaletasuna, Oinarrizko Zeharkako Konpetentziak, Ikaskuntza egoerak.

ABSTRACT: Literary discussion groups are strategies based on dialogue and interaction with pupils. The general objective of this study is to analyse the validity of literary discussion groups when working on basic transversal skills and areas of learning in Pre-School Education. The experience took place at an 'ikastola' [Basque Language Immersion School] in Donostia and 21 pupils (15 girls and 6 boys) from the 5-year-old class participated. Once the conversations about the four stories had been analysed, the appropriateness of the literary discussion groups for working on the areas of experience and basic transversal skills in Pre-School Education became clear. The skills most focused on in the experience were communication, living together and the skill of learning to be. Those receiving less attention were entrepreneurial skills and the skill of learning to learn. In the end, the importance of integral development of pupils in Pre-School Education was underlined, as well as the role of teachers when developing this type of methodological strategy.

KEYWORDS: Literary discussion groups, Pre-school education, Pleasure in reading, Basic transversal skills, Dialogic learning.

* Harremanetan jartzeko / Corresponding author: Pello Aramendi Jauregi. Euskal Herriko Unibertsitatea. Didaktika eta Eskola Antolakuntza Saila. Hezkuntza, Filosofia eta Antropologia Fakultatea. Tolosa Hiribidea 70 Donostia. Gipuzkoa - pello. aramendi@ehu.eus - https://orcid.org/0000-0003-08869-9357

Nola aipatu / How to cite: Aramendi Lekuona, Goiatz; Aramendi Jauregi, Pello. (2019). «Solasaldi Literarioak Haur Hezkuntzan: Donostiako ikastola batean burututako esperientzia». Tantak, 31(2), 175-196. (https://doi.org/10.1387/tantak.21054).

Jasotze-data: 2019/07/30; Onartze-data: 2019/11/11.

ISSN 0214-9753 - elSSN 2444-3581 / ( C) 2019 UPV/EHU

(c) (i) Obra hau Creative Commons Atribución 4.0 Internacional-en lizentziapean dago 


\section{SARRERA}

Haur Hezkuntzan, gaur egun, ohikoa da irakasleek haurrei egunero ipuinak irakurtzea. Irakaslearen irakurketa ozenaren bitartez, literaturak bizitzaren irudi zehatzak proiektatzen ditu, sinbolo multzoen bitartez esperientzia estetikoak, fikziozkoak eta errealak sortuz. Solasaldi literarioekin, haurren eta irakasleen arteko elkarrizketa bidez, hitzak eta sentimenduak partekatzeaz gain, eskola errendimendua eta harremanak ere hobetu daitezke (Flecha eta Álvarez, 2016). Hori horrela izanik, benetan zein puntu arte aprobetxatzen dira gizarte egoerak haurrak irakurle aktibo eta estrategiko izan daitezen, eta gainerako helburuak bete daitezen?

Helduaren ahozko hizkuntza da haurrak ikasteko duen tresna edo erreferentzia. Hizkuntza ingurunea zenbat eta aberatsagoa izan, orduan eta aberatsagoa izango da haurren hizkuntza garapena. Bestalde, hizkuntzaren jabekuntza prozesuak haurraren eskola ibilbidean urteetan jarraitzen du, beraz, urte horietan guztietan, haurraren ingurua, haur literaturak eskaintzen dituen irudi eta hiztegi zirraragarriz inguratua egon beharko lukete. Literatura irakasteko metodo tradizionalak ikasleak irakurtzeko ohitura eta zaletasuna sustatzen zailtasun nabarmenak izan dituenez, beharrezkotzat jotzen da bestelako praktikak bultzatzea. Testuinguru honetan kokatu beharko genituzke solasaldi literarioak.

Irakurketa dialogikoa, Garcia, Martínez eta Villardónen (2016) esanetan, prozesu subjektiboa da, parte hartzaileek norberaz eta inguruaz beren interpretazioak eta gogoeta kritikoak egiten dituztelako. Beste eragileen arteko elkarrizketa bidez irakurketa ulermena areagotzen da, irakurle gisa eta munduko pertsona gisa eraldatzeko aukera emanez. Ruiz eta Bañalesek (2015), berriz, berdintasunean oinarritutako solasaldiak direla azpimarratzen dute, ikasleen arteko elkarreraginean oinarritzen direnak. Beraz, solasaldi literarioa irakurtzeko modu berri bat da, testu baten inguruan bildu eta iritziak partekatzeko gunea. Ikasleen arteko elkarrizketak ikuspegi komunikatibo nabarmena du, literatura plazer iturri izateaz gain, elkarrekin hausnartzeko eta elkarrengandik ikasteko balioak gehituz, bizikidetza hobetuz (Malagón eta González, 2016). Solasaldi literarioa komunitatea eraikitzeko tresna da, eta irakaspenak sortzeaz gain, pertsonen arteko loturak sortzen ditu, hitzen, sentimenduen eta esperientzien trukearen bidez (Jiménez, 2016).

Literatur testuak irakurriz eta irakurketa horietaz baliatuz, norberaren ideiak eta besteenak parteka daitezke (Piquer, 2016). Horrez gain, ikasgelan pertsona heterogeneoen arteko interakzioa bultzatuko litzateke (Billelabeitia eta Gonzalez, 2010). Adituen ahotsen artean, bereziki azpimarragarria da Chambersen (2007) ekarpena, zehazki, Dime (Esadazu) liburuan azaltzen duen egitasmoa, bete-betean egokitzen baita Haur Hezkuntzako bost urteko haurren ezaugarri eta beharretara.

Esadazu elkarrizketa literarioak ikasketarako eta irakurzaletasuna sustatzeko tresnatzat proposatzen da. Hizketaldi mota hau eraginkorra izan 
dadin, zenbait arautara egokitzea besterik ez da behar. Edonor izan daiteke partaide, ariketa honen jarduera modu ordenatuan, kontzentrazioa erabiliz eta errespetu osoz egiten ikastea da; hau horrela izanda, taldeak gero eta ideia konplexuagoak eraikitzea ahalbidetuko du. Esadazu izenarekin, elkarrizketa literarioetan ohikoa zen zergatik galderari buelta eman nahi izan zaio. Galdeketa bat izan beharrean, esatera gonbidatzen ditu ikasleak. Haurrari liburu bat zergatik gustatu zaion galdetzean, haien erreakzioan ilusio galera nabarmentzen da, isiltasuna eta sorbalden keinua. Honen arrazoi garbiena da galderaren izaera erasotzaile eta aztertzailea, irakurleek gustatu izanaren arrazoia jakin beharko balute bezala. Baina arrazoiak ez dira hor bukatzen, zergatik galderaren atzean alderantzizko zentzuzko elementu bat dago. Galdera zabalegia da, eta liburu batez hitz egiteko hobe da xehetasunetatik hastea, pixkanaka interpretazioak eta usteak eraikitzen joateko, eta ez alderantziz, zergatik gustatu zaizu? «protagonistak zergatik jokatzen du modu horretan?» erako galderek, haien usteak agortzera behartzen dute. Arrazoi honengatik, zabalegiak diren galderak saihestu behar dira elkarrizketa literarioetan. Beraz, zergatik galdera kendu nahirik, Chambers-ek Esadazu kontzeptua proposatzen du. Esadazu zer ikusi duzun, zer iruditu zaizun, zerk eman dizun atentzioa. Ikusi duena kontatzeko gonbidapen bat da, eta ez galdeketa bat. Izen hori erabili gabe baina diskurtso berdina defendatzen dute, besteak beste, Garcia, Martínez eta Villardónek (2016) eta Febré, Tarín, Pascual eta Villarejok (2016).

Galdera askotarikoak proposatzen dira irakurketa saioak bideratzeko, galdera egoki batzuen bitartez, elkarrizketarako gogoa, jakin-mina eta loturak egiteko ahalmena eskuratu baitaiteke. Solasaldian zehar egiten diren galderek elkarrizketarekin lotuta egon behar dute. Horretarako, hiru galdera mota desberdintzen ditu Rodriguezek (2017):

- Oinarrizko galderak: zer gustatu zaien, zer ez zaien gustatu, zerk harritu dituen: hitz egitera bultzatzen duten galderak dira.

- Galdera orokorrak: hizkuntzaren eta erreferentziaren esparrua zabaltzen duten galderak dira. Konparazioak eskaintzen dituzte eta elkarrizketara ideiak, informazioa eta iritziak ekartzen laguntzen dute.

- Galdera zehatzak: oraindik aurkitu ez diren berezitasunez hitz egitera bultzatzen eta zuzentzen dute.

Laburbilduz, elkarrizketa saioak ez dira edonolako elkarrizketak, ezaugarri jakin batzuk dituzte. Batetik, elkarrizketa literarioak dira, eta, beraz, gai nagusia liburu baten harira sortua da. Gerta daiteke, liburu berak bizitzako beste hainbat gaitaz hitz egiteko aukera eskaintzea; horrelakoetan, inoiz ez da liburuaren haria galdu behar. Bestetik, elkarrizketa horiek gelan burutuko dira, eta, beraz, ez du lagunarteko edo familiarteko elkarrizketaren tonu bera izango. Egitura jakin bati jarraituko diote eta haur bakoitzak adierazteko aukera izango du. Prozedura irakasle batek gidatuko du eta jardueraren helburu pedagogikoak lortzeaz arduratuko da. Hau guztia eragin- 
korra izan dadin ezinbestekoa da haurra eroso sentitzea, bai eta inklusiboa izatea ere (García, Molina, Grande eta Buslón, 2016).

\section{SOLASALDI LITERARIOAK HEZKUNTZAN}

Haurra gizaki gisa hazteko, komunikazio trebetasunak garatzeko, partekatzeko eta bizitzen eta elkarrekin bizitzen ikasteko, espazio bikaina da ikastetxea. Mundu aberatsa eta askotarikoa (anizkoitza) da, taldekoan, elkartrukerako, interakzioetarako eta ideiak partekatzeko lekua (Gallardo, 2015). Gallardok berak (2015) dio ikastea pertsonen arteko elkarrizketa dela. Elkarrizketak ikaslea ahoz, gorputzez, idatziz, matematika bidez edo modu artistikoan komunikatzera bultzatuko du. Irakaslearen lana bitartekari izatea da: eztabaida sortzea, edozein egoeratan elkarrizketa sustatzea, partaidetza demokratikoa sustatzea, ikerketa prozesuak abiaraztea, eta ikasteko eta lankidetzarako nahia sustatzea. Laburbilduz, haurrari entzutea.

Komunikazio ekintzetako bat elkarrekin irakurtzea da, eta horretarako Haur Hezkuntzan baliabide paregabeak dira ipuinak. Ipuinak ilustratuak, letra handikoak eta orrialdeko hitz gutxikoak izatea, eta testuaren eta irudiaren artean loturak izatea komeni da, haurrak inoiz ikusi ez dituen objektuak eta esperientziak aurkitzeko (Goikoetxea eta Martínez, 2015). Ipuina beti izan da haurrek inguruan dituen errealitate ezberdinak eta liluragarriak azaltzeko gizakiak erabili duen testu mota (Selfa, Fraga eta Berenguéren, 2014). Irakurketa partekatuak eragin zuzena du ahozko hizkuntzaren garapenean, testuaren ezagutzan, zeharkako alfabetatze goiztiarrean eta irakurketaren ikaskuntzan. Liburuen hiztegi aberatsarekin, helduen eta haurren arteko elkarrekintzarekin, sortzen dituen esperientzia emozionalekin eta idatzizko testuaren presentziarekin elikatuko da haurra.

Ahozko hizkuntza alfabetatze goiztiarraren gakoa da, eta estuki lotuta dago irakurketaren ulermenarekin (Goikoetxea eta Martínez (2015). Formei eta funtzioei buruzko ezagutzak ikasten hasten dira, hala nola, testu baten antolakuntza (ezkerretik eskuinera eta goitik behera idazteko norabidea, hitzak, esaldiak, paragrafoak, orrialdeak identifikatzea, testu edo liburu bat osatzen duten elementuak ezagutzea). Liburuek hiztegi aberatsa dute. Gainera, ilustrazioak, horietako asko marrazki forman, hiztegia ikasteko tresna egokiak direla diote, objektu errealak bi dimentsiotan azaltzen direlako eta objektu horien ezaugarri tipikoak lerroz nabarmentzen direlako. Irakurketa partekatuak emozionalki pertsonaien esperientziekin konektatzeko ahalmena ere badu. Hau batez ere, helduak haurrarekin erlazio estua duenean eta haurraren esperientziak istorioko gertakariekin lotzea lortzen denean gertatzen da. Intonazioak, pausak, keinuak eta kontaktu bisualak ere emozioei buruzko informazioa ematen dute, ulermena erraztuz eta istorioan sartzen lagunduz (García, Gairal, Munté eta Plaja, 2018). 
Ikastetxean irakurketak planifikatuta egon behar du, eta ezinbestekoa da espazio eta denbora nahikoa eskaintzea eta ez mugatzea. Irakasleak era guztietako irakurketak sustatzeko bideak eta baliabideak bilatu behar ditu, ikaslearen irakurketa gustuak kontuan hartuz. Liburutegia, ikasteko eta irakasteko eguneroko eszenatokia hurbila da, eta gaur egungo eskaintza editorial askotarikoa aprobetxatuz, liburu egokienekin elikatu behar da (Álvarez, 2018). Ikasturte guztirako edo aldi baterako liburuak egon daitezke, eta azken hauen kasuan, curriculumeko alderdi ezberdinak jorratzeko erabil daitezke. Ikasle, irakasle eta komunitate guztiarentzat eskuragarri egongo da materiala (Aguiló, Florit eta Trobat, 2013).

Irakurketarako baliabideen hurbiltasunak, informazio beharra ase, gaiei buruzko jakin-mina sortu eta irakurketa ohiturak bultzatuko ditu. Finean, Haur eta Lehen Hezkuntzako edozein irakasleren helburu nagusietako bat da beren ikasleak irakurleak izatea, irakurle onak izatea, eta gai eta tipologia ezberdineko liburuak maitatzea eta estimatzea. Horretarako, liburutegiak espazio alaia, motibagarria eta oso funtzionala izan behar du ikasleentzat, eta ezinbestekoa da zeregin honetan bera partaide eta arduradun izatea. Bitartekariaren rola ere funtsezkoa da irakurketa sustatzeko, liburuen eta haurren arteko zubia eraikitzen duelako. Haurren erantzuna, bitartekariaren jarreraren araberakoa izango da. Txikitatik haurra irudi bidezko liburuak partekatzen hasten da, aurrerago, gaztetan estilo, espresio eta ekintza bihurtuko direnak, eta honela, literatura zentzua hartuz joango da (Selfa, Fraga eta Berengué, 2014). Haurrak irakurtzen duenari zentzua aurkitzen badio, aldi berean irakurtzen eta pentsatzen ikasten badu, eta bere sentimenduak ulertzen eta irudikatzen baditu, irakurtzeko zaletasuna eraikitzeko aukera izango du. Prozesua motela eta pixkanakakoa da, eta idatzizko materialarekin gozamena sortzen laguntzeko bitartekaria behar du haurrak. Pertsonaia baten emozioak esperimentatu dituenean, bitartekariak soilik transmiti diezaioke irakurtzeko gogoa haurrari (Sainz, 2005).

Irakasleei garapen pertsonalerako eta profesionalerako prestakuntza eta tresna egokiak ematea beharrezkoa da, haurrei liburuetarako interesa eta gustua sortzen jakiteko. Ikastetxea irakurleak formatzeko espazio ideala da, eta funtsezkoa da bai zuzendariak bai eta irakasleak ere konpromisoa hartzea, denon artean emaitza onenak lortzeko. Ez da nahikoa irakurtzea: zer eta nola irakurri behar den jakin behar da, eta irakasleen formazioa hobetu behar da beren ikasleei praktika egokienak irakasteko. Haur Hezkuntzako irakasleek haur eta gazte literaturako saioak jasotzen badituzte ere, Lehen Hezkuntzako irakasleentzat guztiz boluntarioa da, eta irakaskuntza ertaineko ikasgaietan ez da ia ezer lantzen. Nerabezaroa ordea, irakurketarako maitasuna sendotzeko funtsezko etapa izanik, nola landuko da beren irakasleek ezagutzarik ez badute? (Morán, 2006). Irakasleak ikaslearen eta literaturaren arteko kontaktu aktiboa sustatzeko ardura badu, horretarako prestatua izatea ezinbestekoa izango da (Ibarra eta Ballester, 2013). Beharrezkoa da, beraz, unibertsitatean Haur Hezkuntzatik goragoko mailetan 
formatzen diren irakasleak ere literatura eta filologia nahitaezko ikasgaitzat edukitzea; garrantzitsua da, era berean, ohartaraztea irakaslearen gaiarekiko ezjakintasuna literaturak prestakuntzan duen tokiaren ondorioa dela (Guadamillas, 2015).

\section{LITERATURAK CURRICULUMEAN DUEN LEKUA}

Haur eta gazte literaturak haur eta nerabeen artean duen lekua, gaur egun inork ez du zalantzan jartzen. Haur Hezkuntzako curriculum eremuetan eta ohiko praktiketan txertatuta dago literatura, hizkuntzaren eta komunikazioaren atalean zehazki, eta atal honen barruan, idatziarekin eta irakurketarekin lotutako elementuak daude: liburu ilustratuak, abestiak, olerkiak, poemak... Baliabide hauek irakasle, guraso eta ikasleekin partekatu behar dira elkarrekintza eta komunitate zentzua sortzeko (Colomer, 2005). Hezkuntzan eta, bereziki, Haur Hezkuntzan lantzen diren estrategia metodologikoak ikasleen garapen osoa lortzera bideratu behar dira. Gaur egun indarrean dagoen 237/2015 Haur Hezkuntzako Dekretuaren sarreran (Hezkuntza, Hizkuntza Politika eta Kultura Saila, 2016) haurraren garapen osoa dimentsio eta alderdi guztietan lantzea da hezkuntzaren xedea, eta honetarako familien gertuko lankidetza beharrezkoa dela adierazten da. Erantzukidetasuna, lankidetza eta elkarren onarpena funtsezko jardun-oinarriak dira irakaskuntza-ikaskuntzako prozesuak lantzeko. Haurren garapeneko lehen etapa honetan, haurrek bizitzen dituzten egoerei lotzen zaie hezkuntza-planteamendua, eta, ondorioz, bizipen edo esperientzia-eremuetan egituratzen dira hezkuntza proposamenak. «Norberaren nortasunaren eta ingurune fisiko eta sozialaren eraikuntza» eta «Norberaren nortasunaren eta komunikazioaren eraikuntza eta irudikapena» esperientzia eremuen bidez, Haur Hezkuntzari dagozkion oinarrizko zehar konpetentzien eta diziplinako oinarrizko konpetentzien lorpen mailak erdiesten ditu haurrak.

Horregatik gizartean irakurtzea funtsezkoa da informazioa sartzeko, hezkuntza hobetzeko, eta bizitzan zehar aurkitu genitzakeen mezu ezberdinak ulertzeko. Aldi berean, ezagutza eta garapen pertsonala bultzatzen ditu. Horregatik, eskoletan irakurketaren sustapena oinarrizko eta ezinbesteko tresna da, hezkuntzarako eta kulturarako eskubidea gauzatzeko. Solasaldietan literatura unibertsaleko lan onenak irakurriz, curriculumeko hainbat eremuren ezagutza (hizkuntza, historia, geografia...) eta hiztegia lantzen dira. Ezagutza instrumentalak ere garatzen dira, ikasleek historian zehar ekoiztutako literatura onenak eskuratzen dituzten bitartean. Parte hartzaileen interakzioen bidez ikaskuntza instrumentala hobetzen da, zentzu pertsonala eta soziala garatuz, eta elkartasunaren eta berdintasunaren baloreak eskuratuz. Modu honetan, parte hartzaileek gizartearen ezagutza eraikitzen dute, eta pixkanaka-pixkanaka beren ezagutza gisa barneratzen 
dute (Febré, Tarín, Pascual eta Villarejo, 2016). Hezkuntzak eta eskolak, bereziki, ikaslearen inklusioa bermatu behar du (Álvarez, González eta Larrinaga, 2012).

Lehen aipatu den bezala, Hezkuntza, Hizkuntza Politika eta Kultura Sailaren 237/2015 Dekretuko 3. artikuluan Haur Hezkuntzako xede nagusia haur guztien garapen osoa eta orekatua lortzea da. Dekretu honen zortzigarren artikuluan zera jasotzen da:

2. Konpetentzien araberako pedagogiak ezaugarri nagusi hauek ditu:

a) Problema-egoerak konpontzea, eskura dauden baliabideak modu integratuan erabiliz.

d) Oinarrizko konpetentziak garatu ahal izateko, egoera errealetako jarduerak proposatu behar dira, eguneroko bizitzako problema nagusiak jakintzarekin lotuz.

e) Oinarrizko konpetentziak garatzeko aukera emateko, ikasleak modu aktiboan inplikatu behar du jakintza bilatzen, ikasten, esperimentatzen, hausnartzen, aplikatzen, auto-ebaluatzen eta komunikatzen.

f) Hezitzailearen eginkizuna izango da haurren irakaskuntza-ikaskuntza prozesuan laguntzea eta prozesu horiek gidatzea, eta horretarako prozesuak diseinatu, planifikatu, antolatu, estimulatu, lagundu, ebaluatu eta birbideratu egin behar ditu. (8. or.)

Dekretuko paragrafo horiek irakurri ondoren, kezka hauek sortu zitzaizkigun: Solasaldi literarioak, ikaskuntza estrategia gisa, egokiak al dira Oinarrizko Zeharkako Konpetentziak lantzeko? Solasaldi literarioen bidez, Haur Hezkuntzako bi Esperientzia Eremuak (Ingurune fisikoa eta soziala eta komunikazioa) landu al daitezke? Kezka horiek, gai honetan murgiltzeko aukera eman digute.

\section{METODOA}

\subsection{Helburuak}

Lan honen helburu orokorra da Haur Hezkuntzako Oinarrizko Zeharkako Konpetentziak eta Esperientzia Eremuak lantzeko (5 urteko ikasgelan) solasaldi literarioen ekarpena (baliagarritasuna) baloratzea.

Ikerketa lana bideratzeko, aurreko galderak eta kezkak, honako hiru helburu zehatz hauetan jaso dira:

a) Solasaldi literarioak, Haur Hezkuntzako Esperientzia Eremuak lantzeko (Norberaren nortasuna eta komunikazioa eta Norberaren nortasuna eta ingurune fisikoa eta soziala) egokiak diren aztertzea. 
b) Solasaldi literarioak Zeharkako Oinarrizko Konpetentziak lantzeko (Komunikatzen ikastea, Ikasten Ikastea, Elkarrekin Bizitzen Ikastea, Ekiten eta Izaten Ikastea) lantzeko egokiak diren aztertzea.

c) Solasaldi literarioen inguruan, praktikak hobetzeko hausnarketa eta ekarpenak egitea.

\subsection{Parte-hartzaileak}

Saioak Donostiako ikastola batean landu dira, Haur Hezkuntzako 5 urteko ikasleekin. Ikasgela honetan 21 ikasle daude (15 neska eta 6 mutil), eta denak Donostian bizi dira. Ikasleen familiek maila sozioekonomiko eta soziokultural ertaina edo baxua dute. Guraso euskaldunak dituzten ikasleak lau bakarrik dira.

Solasaldi literarioak ikastolako liburutegian egin dira eta lau saio landu dira. Azkenik esan behar da lanean erabili diren ikasleen izenak asmatuak izan direla, anonimotasunaren printzipioa errespetatzeko.

\subsection{Ikerketaren diseinua eta prozedura}

Ikerketaren diseinua kualitatiboa eta deskriptiboa da. Solasaldi literarioen inguruan lau saio grabatu dira eta lortu den informazioa kategorizatu da eta ondorioak atera dira. Emaitzen kategorizazioa, deskripzioa eta interpretazioa ikerketaren helburuen arabera egin dira, eta Hezkuntza Sailaren 237/2015 Dekretuko Haur Hezkuntzako esperientzia eremuak eta zeharkako konpetentziak kontuan hartu dira. Ikerketa emaitzen sinesgarritasun maila eta balidazioa hobetzeko, informazioaren triangelatzea egin da, EHUko irakasle baten laguntzaren bitartez.

Ikerketa hasi baino lehen, 2018ko azaroan, ikasgela batean lan hau burutzeko (lau saio) erabakia hartu zen. Esperientzia hau martxan jartzeko, ikasleen gurasoei baimena eskatzea erabaki zen. Baimenak jaso ondoren lan saioak prestatzen hasi ginen. Materialak (ipuinak) aukeratzeko irizpide batzuk jarraitu dira: ikasleen adinari egokituak dira, solasaldiak eta parte hartzea bultzatzeko egokienak, ipuinaren edukia eta gertaera esanguratsuenak eta gai eta bizitza egoera hurbilak izatea. Lan saioak ikastetxeko liburutegian burutu dira, ikasgelako ordutegian (9:30-10:30 bitarte). Lau saio horiek 2018ko abenduan (bat), 2019ko urtarrilean (bi) eta otsailean (bat) egin dira. Saio baten egitura (gutxi gorabehera) hau izan da: ipuina irakurri, komentatu, solasaldia burutu eta eskulanak egin. Solasaldi osoan zehar arazoren bat izan dugu (lanaren mugak), batez ere, isiltasunaren gaiarekin. Ikasleekin entzute prozesua lantzea espero genuena baino zailagoa suertatu zaigu. Bestalde, aipatzekoa da gurasoen baimena lortzea ere oso prozesu astuna izan dela. 
Saioak bideratzeko orduan, Chambersen (2007) bitartekaritzarako gomendioak aintzat hartuak izan dira: a) Liburua arretaz irakurtzea, b) Haurrei askatasunez adierazten laguntzea, c) Testuari buruzko iritzia ez plazaratzea, d) Elkarrizketarako gaia inoiz ez inposatzea, aukeraketak eskainiz, e) Haurrei beste pertsonen hizketaldiak ere entzuten laguntzea, f) Taldeak esan duena laburbiltzea, ezagutza sendotzeko,g) Elkarrizketa liburura ekartzen laguntzea, h) Haurrek erantzunak garatzen laguntzea.

\subsection{Tresnak eta materialak}

Solasaldi literarioak ikasgelan garatzeko elkarrizketa gidak diseinatu dira zenbait egileren lana kontuan harturik (Chambers, 2007; Hezkuntza, Hizkuntza Politika eta Kultura Saila, 2016; Martín eta Jiménez, 2013; Romero, Tejada eta Garay, 2017). Elkarrizketa gidako galdera batzuk komunak dira, eta besteak, saio eta ipuin bakoitzari egokituak. Galdera bakoitzaren erantzunak Haur Hezkuntzako esperientzia eremuen arabera eta lantzen den konpetentziaren arabera sailkatu dira.

Bestalde, honako hau da saioetan erabili den galderen eredu malgua:

Oinarrizko galderak:

- Gustatu zaizue?/zerk eman dizue atentzioa?/zerbait gehiago egotea gustatuko litzaizueke?/marrazkiak gustatu zaizkizue?

- Bada gustatu ez zaizuen zerbait? Zatiren bat aspergarria da? Zerbaitekin pena, amorrua sentitu duzue?

Galdera orokorrak:

- Lehendik irakurria al zenuten ipuin hau? Gehiago gustatu al zaizue. Orain? Gutxiago? Berdin? Berriz irakurri nahiko zenukete beste batean?

- Irakurri duzue ipuin honen antza duen istoriorik? Zertan da antzekoa? Zertan da ezberdina?

- Zer esango zeniekete zuen lagunei ipuin honetaz?

- Inoiz pasa al zaizue ipuin honetan gertatutakoa? Liburuaren gertaeraren bat bizitza errealean gerta al daiteke? Zer ezin da inoiz gertatu? Ipuin hau zuek idatziko bazenute, zer izenburu jarriko zeniokete?

- Zein da ipuinaren atal garrantzitsuena zuentzat?

Galderak irizpide hauen arabera diseinatu dira:

- Ikastolako lankideen eta EHUko irakasleen aholkuak.

- Ikasleen adina.

- Solasaldiak eta parte hartzea bultzatzeko egokitasuna.

- Ipuinaren edukia eta gertaera esanguratsuenak.

- Gaia eta bizitza egoera hurbilak. Egoera zehatzetatik, hurbiletik, abiatu eta orokorretara pasa. 
- Hezkuntza Sailako 237/2015 Dekretuko Haur Hezkuntzako Esperientzia Eremuen arabera: Norberaren nortasunaren eta inguru fisikoa eta sozialaren eremua eta Norberaren nortasunaren eta komunikazioaren eraikuntza eta irudikapena.

- Hezkuntza Sailaren 237/2015 Dekretuko Zeharkako Konpetentzien arabera: Hitzez, hitzik gabe eta modu digitalean komunikatzeko konpetentzia, Ikasten eta Pentsatzen Ikastea, Elkarrekin Bizitzen Ikastea, Ekiten eta Izaten Ikastea).

Hona hemen, irudi batean, Esperientzia Eremuak eta Oinarrizko Zeharkako Konpetentzien zerrenda:

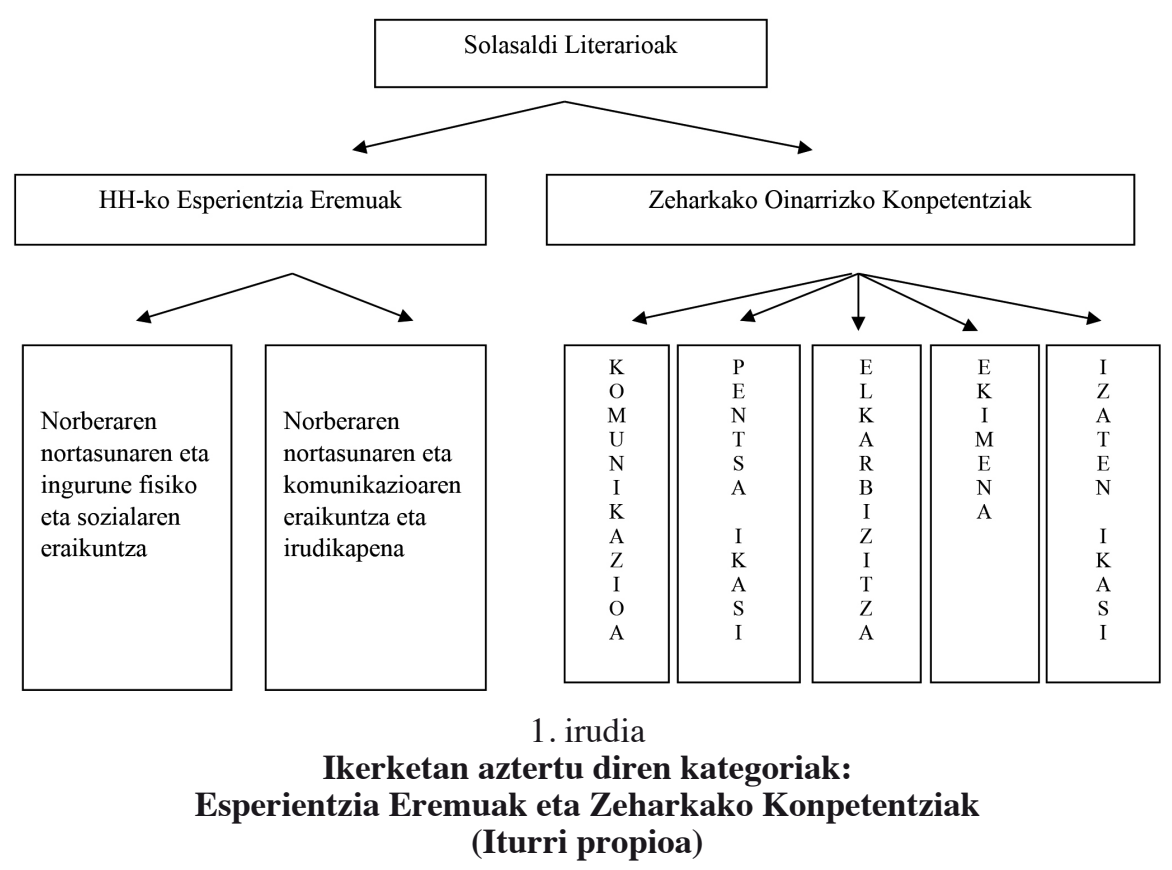

Tresnaren baliozkotasun teorikoa bermatzeko, EHUko eta Ikastolako Haur Hezkuntzako lankideei galdeketa gidoiak bidali zaizkie. Horien azterketa egin ondoren, galdera pare bat aldatu dira, Haur Hezkuntzako Oinarrizko Konpetentzien eta Esperientzia Eremuen inguruan. Galderak beste era batera planteatu dira.

Materialei dagokienez, lau ipuin hauek landu dira, saio bakoitzean bana:

- Lehen ipuina: Browne, A. (2018). Kezkamuxelak. Iruñea: Pamiela. 
- Bigarren ipuina: Aguilar, L. (2018). Tximeleta belarriak. Iruñea: Pamiela.

- Hirugarren ipuina: De Dios, O. (2016). Munstro Arrosa. Lizarra: Cenlit Ediciones.

- Laugarren ipuina: Sendak, M. (2009). Piztiak bizi diren lekuan. Pontevedra: Kalandraka.

\section{IKERKETAREN EMAITZAK}

Espazio arazoak direla eta, esperientziaren emaitzak laburtu egin dira, eta helburuen arabera azalduko dira.

\subsection{Emaitzak lehen helburuaren arabera}

Lehen helburua (Solasaldi literarioak, Haur Hezkuntzako Esperientzia Eremuak lantzeko - Norberaren nortasuna eta komunikazioa eta Norberaren nortasuna eta Ingurune Fisikoa eta Soziala - egokiak diren aztertzea).

Hemendik aurrera ipuin bakoitzaren azterketa azalduko da. Espazio falta dela eta, emaitzak laburtu egin dira, eta haurren elkarrizketa esanguratsuenak bakarrik azalduko ditugu.

\subsubsection{Lehen ipuina: KEZKAMUXELAK. Esperientzia Eremuen azterketa.}

Haur Hezkuntzan, haurrek bizitzen dituzten egoerei lotzen zaie hezkuntza planteamendua, eta, ondorioz, bizipen edo esperientzia eremuetan egituratzen dira hezkuntza proposamenak: «Norberaren nortasunaren eta ingurune fisiko eta sozialaren eraikuntza» eta «Norberaren nortasunaren eta komunikazioaren eraikuntza eta irudikapena» (Hezkuntza, Hizkuntza Politika eta Kultura Saila, 2016, 4. orr.).

Lehen ipuinaren inguruan emaitza hauek azpimarratu daitezke:

a) Eremuei dagokienez, komunikazioa eta irudikapena nabarmenki gehiago lantzen da (72 esaldi) ingurune fisikoa eta soziala baino (16 esaldi).

b) Landu diren gaiei dagokienez, aipatuena beldurra izan da, eta honi buruzko adibideak ere jarri dituzte. Beldurraren aurrean familiaren babesa lortu nahi izan dute ikasleek. Penaren sentimendua eta gurasoen erantzunak ere azaldu dira.

Emaitzen garapena laburtuko da artikuluaren irakurketa astuna izan ez dadin. Hona hemen adibide batzuk:

Ipuin honen gairik aipatuenetakoa beldurra da. Ikasleek dituzten pertzepzioak beldurrari buruz hauek dira: 
EÑAUT: Ibairi nire berdina gertatzen zaiola, ni ere amonaren etxera joatean beldurtu egiten naiz gauetan ... (Komunikazioa eremua).

ANE: Ba norbaitek beldurra pasatzen badu kezkamuxel bat egiteko (Komunikazioa eremua).

ANE: Nik ere bakarrik lo egitean batzuetan beldurra pasatzen dut, ametsak izaten ditudalako edo ezin dudalako lo hartu (Komunikazio ereтиа).

Beldurren inguruko adibideak ere jarri dituzte ikasleek:

INTZA: Ba niri, ez zaizkit burutik inoiz kentzen, zeren Uxuek (gelakideak) esan zidan sorginarena, maltzurrena, eta orain ezin dut inoiz bakarrik lo lasai egin. Eta Oihanari ohera igel bat sartu zitzaiola, Uxueren amari. Eta niri beldurra ematen dit, eta tapatu behar naiz goraino. (Eremu soziala eta komunikatiboa).

Penaren sentimendua ere azaltzen solasaldietan:

NORA: Niri Elsak pena ematen dit, eta horretaz amesten dut gauetan. Hegal bat kendu zioten ... (Komunikazio eremиa)

INTZA: Bai kentzen diote, baina hori ez da gaiztoa izatea (Komunikazio ereтиa).

\subsubsection{Bigarren IPUINA: TXIMELETA BELARRIAK. Esperientzia Eremuen azterketa}

Bigarren ipuinaren inguruan emaitza hauek azpimarratu daitezke:

a) Esperientzia eremuei dagokienez, bi eremuak era orekatuan landu dira (komunikazioa eta irudikapena, 37 esaldi, eta ingurune fisiko eta soziala, 40 esaldi). Ipuin honen bitartez, frogatzen da solasaldi literarioak egokiak eta baliagarriak direla Haur Hezkuntzako bi eremuak lantzeko.

b) Ipuinean landutako gaiei dagokienez, gai nagusia iseka izan da, eta iseka egitearen ondorioez eta hartu beharreko jarrerez hitz egin zen.

c) Irakaslearen rolari dagokionez, kasu honetan bi eremuak era orekatuan landu dira, gaiak berak aukera gehiago eman duelako.

Hona hemen adibide batzuk:

Landu diren gai nagusiak portaera sozialen ingurukoak dira eta, batez ere, isekarekin lotutako pasarte politak azaldu dira:

Ipuin honetan landu den gai nagusia iseka da:

MARE: Ba lagunek Maddiri burla egiten diotela (Komunikazio ereтиа). 
SARA: Iseka egiten diote (Komunikazio eremua).

INTZA: Eta niri batzuetan ere egiten didate iseka, batzuetan lehengusinak (Eremu soziala).

Eta iseka egitearen ondorioak ere aztertzen dira:

SARA: Maddiri inporta zaio burla egitea, baina agian berak beste ipuin batean ere egingo die lagunei, agian ... (Koтиnikazio eremua eta егети soziala).

EÑAUT: Ba deitzen da Maddi ere, gure gelakoa bezala, eta esaten diote gauza itsusiak ... eta Maddiri ere bere lehengusuak. Orduan agian Maddi gure laguna haserretuko da (Eremu soziala).

EÑAUT: Haserretu eta gainera triste jarriko da (Komиnikazio ereтиa eta ereти soziala).

Iseka egitearen aurrean hartu beharreko jarrera ere komentatzen da:

MARE: Ezin da egin iseka ikastolan, bestela batzuk haserretzen dira eta... Niri ez dakit zeinek egin zidan harramazka, zergatik hemen daukat marka bat eta ez zitzaidan gustatu (Eremu soziala).

MARE: Egiten diote Maddiri hori zeren gaiztoak dira, eta agian beste ipuin batean esaten diote gauza gehiago... eta triste jarriko da (Komunikazio егетиа).

SARA: Lagunak onak izan behar dute (Eremu soziala).

MARE: Borroketan ari baldin badira, beste lagunak laguntzera sartu behar dugu (Eremu soziala).

UXUE: Eta ez baldin badute behar laguntzarik, ez lagundu, baina gero eskatzen baldin badute bai (Eremu soziala).

MARE: Ez, gero eskatzen badute ez egin kasu, zeren hasieran ez digute eskatu... (Eremu soziala).

EIDER: Denak gera ezberdinak (Komunikazio егетиа eta егети soziala).

\subsubsection{Hirugarren ipuina: MUNSTRO ARROSA. Esperientzia Eremuen azterketa}

Hirugarren ipuinaren inguruan hauxe adieraz daiteke:

a) Esperientzia eremuei dagokienez, komunikazioa eta irudikapena gehiago landu da (49 esaldi) ingurune fisikoa eta soziala baino (28 esaldi). Ipuin honen bitartez, frogatzen da solasaldi literarioak egokiak eta baliagarriak direla Haur Hezkuntzako bi eremuak lantzeko.

b) Landutako gaiei dagokienez, kanpotik etorritako pertsonen inguruan hitz egin genuen, eta pertsona beltzak pobreziaren kontzeptua- 
rekin lotu zituzten. Bizitza duinaren gaia ere atera zen, eta aukera eman zuen ingurune soziala lantzeko.

c) Irakaslearen rolari dagokionez, eremuen desoreka azaltzen da.

Hona hemen adibide batzuk:

Hirugarren ipuin honetan gai interesgarri bat azaltzen da: kanpotik etorritako pertsonak:

JARE: Nire lagun batzuk deitzen direla Sergio eta Maria, eta etorri ziren nire etxe ondora bizitzera, oso urrutitik (Eremu soziala).

GARAZI: Nik lehengusu bat dut, Txinatik ekarri genuen (Еrети soziala).

GARAZI: Hemendik beste nonbaitera joatea norbait, eta beste nonbaitetik guregana etortzea gerta daiteke (Eremu soziala).

JARE: Zoriontasunaren bila, hobeto bizitzeko (Eremu soziala).

Eta bizitza duinaren kontzeptua ere lantzen da:

IRAKASLEA: Hobeto bizitzeko, zer esan nahi duzu horrekin? Esadazu...

JARE: Ba etxe hobea edukitzeko, edo lagunak, edo janaria... edo ikastola (Eremu soziala).

\subsubsection{Laugarren ipuina: PIZTIAK BIZI DIREN LEKUAN. Esperientzia Eremuen azterketa}

Laugarren ipuinari buruz hauxe ondoriozta dezakegu:

a) Esperientzia eremuei dagokienez, komunikazioa eta irudikapena gehiago landu da (44 esaldi) ingurune fisikoa eta soziala baino (19 esaldi). Ipuin honen bitartez, frogatzen da solasaldi literarioak egokiak eta baliagarriak direla Haur Hezkuntzako bi eremuak lantzeko.

b) Landutako gaiei dagokienez, denboraren kontzeptua, espazioaren, errealitatearen eta fantasiaren gaiak jorratu ditugu, eta portaeraren eta zigorraren inguruan ere hitz egin dugu. Ipuinari izenburua jartzera ere animatu dira. Espazioaren eta denboraren kontzeptuak oso garrantzitsuak dira haurraren garapen psiko-ebolutiboa sustatzeko. deak:

Laugarren ipuinean, gai ezberdinak lantzen dira. Hona hemen adibi-

Ipuina ulertu ondoren izenburu berri bat jartzera animatzen dira:

IRAKASLEA: Ipuin hau zuek idatziko bazenituzte, zer izenburu jarriko zeniekete? 
GARAZI: Nik «Piztiak eta Max» (Komunikazio eremua).

MADDI: Nik «piztia parranderoak» (Komunikazio eremua).

LIDE: Nik «Max basoan» (Komunikazio eremua).

JOSUNE: Nik «Max erregea» (Komunikazio eremua).

AFRIKA: Nik «Max bihurria», amak zigortu egin duelako (Komunikazio егетиа).

Denboraren kontzeptua ere aztertzen da:

IRAKASLEA: Zenbat luzeko denboran uste duzue pasa dela istorioa?

JARE: Bidaia luzea egin zuen txalupan, ordu askoan (Komunikazio егетиа).

Espazioaren gaia ere bai:

IRAKASLEA: Eta non uste duzue pasa dela istorioa?

GARAZI: Maxen etxean eta piztien etxean (Eremu soziala).

JOKIN: Eta itsasoan, itsasontzian (Eremu soziala).

MAIA: Ez, niri amatxok esan zidan gelan gertatu dela dena, Maxen pentsamenduak direla. Pentsatzen aritu da piztiez eta horrela (Eremu soziala).

Errealitatea eta fantasia...

IRAKASLEA: Max erreala dela uste duzue? Eta piztiak?

JOSUNE: Max bai, piztiak ez (Eremu soziala).

JOKIN: Piztiak ez eta piztiak ere ez, ipuin bat da (Eremu soziala)

JARE: Max mutil normal bat da (Котипikazio ereтиa).

JOKIN: Baina ez dugu ezagutzen eta ez da existitzen (Eremu soziala).

JARE: Ez, keba! Piztiak ez dira animaliak (Eremu soziala).

Solasaldi literarioen bitartez Haur Hezkuntzako bi esperientzia eremuak landu dira: komunikazioa eta irudikapena eta ingurune fisikoa eta soziala.

\subsection{Emaitzak bigarren helburuaren arabera}

Bigarren helburua (Solasaldi literarioak Zeharkako Oinarrizko Konpetentziak lantzeko -Komunikatzen ikastea, Ikasten Ikastea, Elkarrekin Bizitzen Ikastea, Ekiten eta Izaten Ikastea - lantzeko egokiak diren aztertzea). Lehen bezala, hasieran, azterketa ipuinaren arabera egingo dugu, eta, azkenik, ondorioak azalduko ditugu. 


\subsubsection{Lehen ipuina: KEZKAMUXELAK. Zeharkako Oinarrizko Konpetentzien azterketa.}

Zeharkako konpetentziei dagokienez, lehen ipuinean zera ondoriozta daiteke: Hitzez, hitzik gabe eta modu digitalean komunikatzeko konpetentzian 52 esaldi agertzen dira, Elkarbizitzarako konpetentzian 26 esaldi, Izaten ikasteko konpetentzian 17 esaldi. Azpimarratu behar dugu Ekimenerako eta ekiteko konpetentzia (7 esaldi) eta Ikasten eta pentsatzen ikasteko konpetentzia ( 3 esaldi) oso gutxi landu direla. Bitartekaritza rola agian ez da egokiena izan. Halaz ere, solasaldi literarioak zeharkako konpetentziak lantzeko baliagarriak direla frogatzen da.

Konpetentzia hauek nola lantzen diren, adibideen bitartez azalduko dugu:

a) Komunikazio konpetentziaren inguruan (Hitzez, hitzik gabe eta modu digitalean komunikatzeko konpetentzia) 52 esaldi aurkitu dira ipuin honetan. Esaldi esanguratsuen artean hauek azpimarratu dira:

Ikasleen kexkamuxelak deskribatzen dira solasaldietan:

IRAKASLEA: Ia ba! Banaka-banaka has gaitezen komentatzen. Leire hasi...

LEIRE: Nire kezkamuxela Eider deitzen da, eta, nirea bezala, ile horia egin diot. Eta gona bat egin diot kartulinarekin! (Hitzez, hitzik gabe eta modu digitalean komunikatzeko konpetentzia).

IRAKASLEA: Oso polita, Eider! Etxean ohearen ondoan jarriko duzu?

LEIRE: Bai!' (Komunikazioa; izaten ikasteko konpetentzia).

IRAKASLEA: Primeran! Ea hurrengoa...

EÑAUT: Nik Jon jarri diot izena, izena gustatzen zaidalako (Komunikazioa, izaten ikasteko konpetentzia).

MARE: Nik jarri dut superpolita soineko arrosarekin, eta gainean marra batzuk egin dizkiot, ikusi... Eta ile berdea jarri diot. Nik beltza nahi nuen, baina ez zegoen (Hitzez, hitzik gabe eta modu digitalean komunikatzeko konpetentzia).

b) Ikasten eta Pentsatzen Ikastea konpetentziaren inguruan ikasleen esaldi gutxi daude:

ANDONE: Nik beti amesten ditut amesgaiztoak. Egun batean amestu nuen gauza bat oso beldurgarria. Beldur handia eman zidan eta amaren ohera joan nintzen lasaitzeko (Hitzez, hitzik gabe eta modu digitalean komunikatzeko konpetentzia eta pentsatzen ikastea konpetentzia). 
IRAKASLEA: Beraz, gehienok beldurra, amorrua sentitzen duzue gauetan esna zaudetela eta amets gaiztoak egitean.

EÑAUT: Bai, amets onak egitean lo ongi egiten dugu eta horregatik ez gara gogoratzen (Ikasten eta pentsatzen ikastea konpetentzia).

\subsubsection{Bigarren ipuina: TXIMELETA BELARRIAK. Zeharkako Oinarrizko Konpetentzien azterketa}

Zeharkako konpetentziei dagokionez, bigarren ipuinen zera ondoriozta dezakegu: hitzez, hitzik gabe eta modu digitalean komunikatzeko konpetentzian, 33 esaldi agertzen dira, Elkarbizitzarako konpetentzian 26 esaldi, Izaten ikasteko konpetentzian 25 esaldi. Azpimarratu behar da Ekimenerako eta ekiteko konpetentziari (4 esaldi) eta Ikasten eta pentsatzen ikasteko konpetentziari ( 0 esaldi) dagokienez bat oso gutxi eta bestea ez dela batere landu. Hemen ere, solasaldi literarioak zeharkako konpetentziak lantzeko baliagarriak direla frogatzen da, betiere irakasleak bitartekaritza lana ondo egiten badu.

Konpetentzia hauek nola lantzen diren azalduko dugu adibideen bidez:

a) Elkarbizitzaren konpetentziaren inguruan 26 esaldi kategorizatu dira. Ikasleen esaldi hauek azpimarratu daitezke:

IRAKASLEA: Zenbat gauza esateko ... Zer sentituko zenukete Maddi izango bazinete?

ANDONE: Niri ez zait gustatzen lagunek niri iseka egitea, triste jartzen naiz (Izaten ikasteko konpetentzia).

INTZA: Bai, bihotzean ematen du mina (Komunikazioa; izaten ikasteko konpetentzia).

LEIRE: Marrazkietan Maddi ez dago triste (Hitzik gabe eta modu digitalean komunikatzeko konpetentzia).

INTZA: Bai, nahiz eta negarrez ez egon, bihotzean mina ematen dio berdin-berdin (Hitzez, hitzik gabe eta modu digitalean komunikatzeko konpetentzia; izaten ikastea).

IZAR: Maddik gauza dibertigarriak esaten ditu! (Elkarbizitza).

IRAKASLEA: Lagunen hitz itsusiei alde ona ateratzen die, ezta?

HAURRAK: Bai (Soziala; elkarbizitzarako konpetentzia).

\subsubsection{Hirugarren ipuina: MUNSTRO ARROSA. Zeharkako Oinarrizko Konpetentzien azterketa.}

Zeharkako konpetentziei dagokionez, hirugarren ipuinean zera ondoriozta daiteke: hitzez, hitzik gabe eta modu digitalean komunikatzeko konpetentzian 48 esaldi agertzen dira, Elkarbizitzarako konpetentzian 21 esaldi, eta Izaten ikasteko konpetentzian 18 esaldi. Azpimarratu behar da Ekimenerako eta ekiteko konpetentzia ( 1 esaldi) eta Ikasten eta pentsa- 
tzen ikasteko konpetentzia (1 esaldi) esaldi bakar batean landu direla. Hemen ere, frogatzen da solasaldi literarioak baliagarriak direla zeharkako konpetentziak lantzeko.

Ipuin honetan azpimarratu diren pasarte nagusiak hauek dira:

a) Elkarbizitzaren konpetentziaren inguruan 21 esaldi identifikatu dira. Atzerritarren gaia komentatzen da:

MADDI: Nire lagun batzuk etorri dira hona, oporretara, ezagutzera gure herria, mutil bat eta neska bat (Elkarbizitzarako konpetentzia).

JARE: Nire herrira etorri ziren beltz batzuk (Elkarbizitzarako konpetentzia).

JARE: Eta guk batzuetan lagundu egiten diegu, eta Afrikara ere janaria bidaltzen dugu (Elkarbizitzarako konpetentzia).

MAIA: Bai, eta hemen ikastolan ere. Nik atzo ekarri nuen arroza beraiei bidaltzeko (Elkarbizitzarako konpetentzia).

IRAKASLEA: Beraz, jende berria ere ongi etorria da zuen inguruan, ezta?

HAURRAK: Bai! (Elkarbizitzarako konpetentzia, eta izaten ikasteko konpetentzia).

AFRIKA: Beltzak hemen hobeto bizi dira (Elkarbizitzarako konpetentzia).

JARE: Zeren hor ez daukate janaria, eta daukate ur zikina. Eta etortzen dira hona jatera eta edatera ur eta janari pixka bat (Elkarbizitzarako konpetentzia).

MADDI: Gehiena zopa (Elkarbizitzarako konpetentzia).

b) Ekimenerako eta ekiteko konpetentziaren inguruan esaldi bakarra identifikatu da:

IRAKASLEA: Eta zuk, Arane?

ARANE: Nik Maialeni kopiatu diot (Ekimena konpetentzia).

IRAKASLEA: Eta zergatik ez duzu zuk asmatu?

ARANE: Ez nekien zer egin.

\subsubsection{Laugarren ipuina: PIZTIAK BIZI DIREN LEKUAN. Zeharkako Oinarrizko Konpetentzien azterketa}

Zeharkako konpetentziei dagokionez, laugarren ipuinean zera ondorioztatzen da: Hitzez, hitzik gabe eta modu digitalean komunikatzeko konpetentzian 40 esaldi agertzen dira, Elkarbizitzarako konpetentzian 13 esaldi, eta Izaten ikasteko konpetentzian 8 esaldi. Azpimarratu behar dugu Ekimenerako eta ekiteko konpetentziari (0 esaldi) eta Ikasten eta pentsatzen ikasteko konpetentziari ( 3 esaldi) dagokienez bat ez dela batere landu eta bestea oso gutxi landu dela. Hemen ere, frogatzen da solasaldi li- 
terarioak zeharkako konpetentziak lantzeko baliagarriak direla, betiere irakasleak bitartekaritza lana ondo egiten badu.

Ipuin honetan gai bereziak landu dira: espazioa eta denbora, fikzioa... Hona hemen adibide bat:

a) Izaten Ikasteko konpetentziaren inguruan ikasleen 8 esaldi identifikatu dira. Gehienak bere sentimenduak eta gustuak adierazten dituztenak:

MADDI: Bai, eta zuhaitz bat eta eguzkia egin dut (Komunikazioa; hitzez, hitzik gabe eta modu digitalean komunikatzeko konpetentzia).

IRAKASLEA: Zuri adar bakarrak gustatzen zaizkizu; bai, primeran! Ea, Haizea, esan...

HAIZEA: Nik alde batean nire logelako ohea egin dut, eta beste aldean mundu bat (Soziala; Komunikazioa, hitzez, hitzik gabe eta modu digitalean komunikatzeko konpetentzia).

IRAKASLEA: Hara, zein ederki! Zer mundu egin duzu?

HAIZEA: Ez dakit (Komunikazioa; hitzez, hitzik gabe eta modu digitalean komunikatzeko konpetentzia).

IRAKASLEA: Ea, Garazi, zure txanda...

GARAZI: Nik ere logela baso bihurtu dut, eta ohea, zuhaitzak eta loreak egin ditut. (Komunikazioa; hitzez, hitzik gabe eta modu digitalean komunikatzeko konpetentzia).

Lau ipuinetan, maila ezberdinetan, Haur Hezkuntzako Zeharkako Konpetentziak landu dira.

\section{LANAREN ONDORIOAK, MUGAK ETA HOBEKUNTZA PROPOSAMENAK}

Lehen helburuari dagokionez (Solasaldi literarioak, Haur Hezkuntzako Esperientzia Eremuak lantzeko -Norberaren nortasuna eta komunikazioa eta Norberaren nortasuna eta Ingurune Fisikoa eta Soziala - egokiak diren aztertzea), lau ipuinetan eremu komunikatiboa landu da batez ere. Lau ipuinetatik hirutan, eremu komunikatiboa gehiago landu da eremu fisikoa eta soziala baino. Aldiz, lau ipuinetatik batean, bai eremu komunikatiboa eta bai eremu fisikoa eta soziala era orekatuan landu dira. Landutako gaiei dagokienez, hauei buruz hitz egin da: beldurra, pena, familia, iseka, gizarte estereotipoak, kanpotik etorritako pertsonak, bizitza duina, denboraren kontzeptua, espazioa, errealitatea eta fantasia, eta portaera eta zigorrei buruz. Gai horiek, beren ingurune fisiko eta sozial hurbila ezagutzeko balio izan dute. Ados gaude Flecha eta Álvarezekin (2016) eta López de Aguiletarekin (2019), esaten dutenean solasaldi literarioen lanketak ikaslearen garapen komunikatiboa, soziala eta emozionala hobetzen dituela. 
Bigarren helburuari dagokionez (Solasaldi literarioak Zeharkako Oinarrizko Konpetentziak lantzeko - Komunikatzen ikastea, Ikasten Ikastea, Elkarrekin Bizitzen Ikastea, Ekiten eta Izaten Ikastea-lantzeko egokiak diren aztertzea), lau ipuinetan ikasten ikastea eta ekiten ikastea konpetentziak ez dira askorik lantzen. Ikaskuntza egoera hau koiunturako egoera izan daiteke, ez delako derrigorrezkoa irakasleak konpetentzia bakoitza ipuin guztietan lantzea. Egungo gizartean bizitzeko, ikasle guztiek gai izan behar dute elkarrekin komunikatzeko eta ideiak argudiatu eta adosteko, horiek baitira bizikidetzaren oinarriak (Garcia, Martínez eta Villardón, 2016). Solasaldi literarioa, gure iritziz, baliabide interesgarria da konpetentzia horiek lantzeko.

Hirugarren helburuari dagokionez (Solasaldi literarioen inguruan, praktika hobetzeko hausnarketa eta ekarpenak egitea), bitartekaritza lana azpimarratu nahi da. Chambersek (2007) dioen bezala, solasaldi literarioak lantzeko honako elementu hauek hartu behar dira kontuan: liburua arretaz irakurtzea, haurrei askatasunez adierazten laguntzea, testuari buruzko iritzia ez plazaratzea, elkarrizketarako gaia inoiz ez inposatzea, aukeraketak eskainiz, haurrei beste pertsonen hizketaldiak ere entzuten laguntzea, ezagutza sendotzeko taldeko ideiak eta ekarpenak laburbiltzea, elkarrizketa liburura ekartzen laguntzea eta haurrei erantzunak garatzen laguntzea. Zeregin horiek irakaslearen bitartekaritza lanaren bitartez gauzatzen dira. Irakasleak bitartekari lana egiten du, ezagutzak bideratzen baititu (López, Encabo eta Jerez, 2016; Tébar, 2003). Ikaslearen gaitasun komunikatiboak, sozialak eta emozionalak lantzeko, ezinbestekoa da hezitzailearen bitartekaritza, eta hori modu egokian egiteko, hark formazioa iraunkorra behar du (Bravo, Gallardo, Santos eta Gutiérrez, 2014; Marín eta Buslón, 2015).

Inoiz ez da goizegi haurrekin liburu bat partekatzeko (Hezkuntza, Hizkuntza Politika eta Kultura Saila, 2019). Irakurtzen ikasi arte itxarotea, hitz egiteko hitz egiten ikasi arte itxarotea bezala izango litzateke. Solasaldi literarioekin, ikasleen eta irakasleen arteko elkarrizketaren bidez, hitzak eta sentimenduak partekatzeaz gain, eskola errendimendua eta harremanak ere hobetzen dira. Ikasleak, zailtasunak kudeatu eta bere gaitasun guztiak garatu ahal izateko, konfiantza izan behar du bere buruarengan, besteengan eta inguratzen duen horretan. Konfiantza hori eraikitzen laguntzeko baldintza egokiak sortzea da hezitzaileen egitekoa (Ruiz eta Bañales, 2015). Ondorioztatu ahal izan denez, solasaldi literarioak eta dialogikoak tresna baliagarriak eta arrakastatsuak dira ikaslearen konpetentziak eta esperientzia eremuak lantzeko, inklusioa eta lankidetza bultzatzeko eta, finean, haurraren garapena osotasunean lantzeko. Baliabide egoki bezain garrantzitsua izanik, arreta berezia jarri beharko litzateke irakasleen prestakuntzan (Flecha eta Álvarez, 2016; Sancho, 2016).

Bukatzeko, lan honen berezko mugak aipatu behar dira. Ikerketa honen lagina txikia da eta lortutako emaitzak testuinguru zehatz horri baino ezin zaizkio aplikatu. Baliabidearen aukerak handiak direnez, hurrengo lanetan lagina zabaldu eta gai honetan sakontzen saiatuko gara. 


\section{ERREFERENTZIAK}

Aguilar, L. (2018). Tximeleta belarriak. Iruñea: Pamiela.

Aguiló, L., Florit, LI. eta Trobat, C. (2013). La bibilioteca de la escuela, un espacio vivo. Aula de Innovación Educativa, 222, 43-47.

Álvarez, C., González, L. eta Larrinaga, A. (2012). Aprendizaje dialógico, grupos interactivos y tertulias literarias: una apuesta de centro educativo que favorece la inclusión. Madrid: Narcea.

Álvarez, C. (2018). A Qualitative Study on Book Clubs and Dialogic Literary Gatherings in Spain and Brazil. Public Library Quarterly, 38(1), 72-84. https:// doi.org/10.1080/01616846.2018.1530032

Billelabeitia, M. eta González, A. (2010). El aprendizaje dialógico a través de las tertulias literarias de los clásicos. Arbela, 42, 50-53.

Bravo, E., Gallardo, E., Santos, I. eta Gutiérrez, A. (2014). Investigaciones sobre la enseñanza del español y su cultura en contextos de inmigración. Sevilla: Universidad de Sevilla.

Browne, A. (2018). Kezkamuxelak. Iruñea: Pamiela.

Chambers, A. (2007). Dime: los niños, la lectura y la conversación. Mexiko: Fondo de Cultura Económica.

Colomer, T. (2005) El desenlace de los cuentos como ejemplo de las funciones de la literatura infantil y juvenil. Revista de Educación, $N^{o}$ Extra 1, 203-216.

De Dios, O. (2016). Munstro Arrosa. Lizarra: Cenlit Ediciones.

Febré, B., Tarín, A. Pascual, D. eta Villarejo, B. (2016). Tertulias literarias dialógicas. Padres y Maestros, 367, 22-26. Doi: pym.i367.y2016.004

Flecha, R. eta Álvarez, P. (2016). Fomentando el Aprendizaje y la Solidaridad entre el Alumnado a través de la lectura de clásicos de la Literatura Universal: El caso de las Tertulias Literarias Dialógicas. Educación, Lenguaje y Sociedad 13(13), 1-19. Doi: http://dx.doi.org/10.19137/els-2016-131302

Gallardo, I. (2015). Aprender como forma de relación en Educación Infantil. Ensayos. Revista de la Facultad de Educación de Albacete, 30(2), 37-52.

García, C., Gairal, R., Munté, A. eta Plaja, T. (2018). Dialogic literary gatherings and out-of-home child care: Creation of new meanings through classic literature. Child \& Family Social Work, 23(1), 62-70. https://doi.org/10.1111/cfs.12384

García, R., Martínez, Z. eta Villardón, L. (2016). Tertulias literarias dialógicas: herramienta para una educación de éxito. Padres y Maestros, 367, 42-47. Doi: pym.i367.y2016.008

García, R., Molina, S., Grande, L. A. eta Buslón, N. (2016). Análisis de las Interacciones entre Alumnado y Diversas Personas Adultas en Actuaciones Educativas de Éxito: Hacia la Inclusión de Todos y Todas. Revista Latinoamericana de Educación Inclusiva, 10(1), 115-132.

Goikoetxea, E., eta Martínez, N. (2015). Los beneficios de la lectura compartida de libros. Educación XX1 , 18(1), 303-324. Doi: 10.5944/educXX1.18.1.12334

Guadamillas, M.V. (2015). La formación de los futuros maestros a través de la literatura: los textos literarios desde una perspectiva didáctica-practica. Investigaciones Sobre Lectura, 4, 93-106.

Hezkuntza, Hizkuntza Politika eta Kultura Saila (2016). 237/2015 Dekretua abenduaren 22koa, Haur Hezkuntzako curriculuma zehaztu eta Euskal Autono- 
mia Erkidegoan ezartzekoa. Gasteiz: Eusko Jaurlaritza. Berreskuratua: https:// www.euskadi.eus/y22-bopv/eu/bopv2/datos/2016/01/1600142e.pdf

Hezkuntza, Hizkuntza Politika eta Kultura Saila (2019). Irakurgunea. Euskadiko Irakurketa Plana. Gasteiz: Eusko Jaurlaritza. Berreskuratua: https:// irakurgune.euskadi.eus/eu

Ibarra, N. eta Ballester, J. (2013). La literatura infantil y juvenil en la formación del maestro. Lenguaje y Textos, 38, 11-18.

Jiménez, E. (2016). Aportes del Departamento de Orientación en el desarrollo de la comprensión lectora. Debates \& Prácticas en Educación, 12, 18-34.

López, A., Encabo, E. eta Jerez, I. (2016). Consideraciones docentes e investigadoras para la Didáctica de la literatura en Educación Infantil y en Educación Primaria. Lenguaje y textos, 43, 7-14.

Lopez de Aguileta, G. (2019). Developing School relevant Language and Literacy Skills through Dialogic Literary Gatherings. International Journal of Educational Psychology, 8(1), 51-71. Doi: 10.17583/ijep.2019.4028

Malagón, J. D. eta González, I. (2016). Evaluación del impacto de las Tertulias Literarias Dialógicas en Comunidades de Aprendizaje. Profesorado. Revista de Currículum y Formación del Profesorado, 22(4), 111-132. Doi: 10.30827/ profesorado.v22i4.8400

Marín, N. eta Buslon, A. (2015). Tertúlies literàries dialògiques. Guix: Elements d'acció educativa, 414, 21-24.

Martín, M. I. eta Jiménez, A. (2013). Las tertulias dialógicas, un desafío para la creatividad y la convivencia. Revista Creatividad y Sociedad, 21, 1-21.

Morán, C. (2006). Los especialistas piden incluir la literatura juvenil en la formación de los profesores. El País Educación, 11-XII-2006.

Piquer, I. (2016). La adquisición del proceso lector en Lengua Extranjera. REICE. Revista Iberoamericana sobre Calidad, Eficacia y Cambio en Educación, 14(1), 37-47. Doi: 10.15366/reice2016.14.1.002

Rodríguez, N. (2017). Enseñanza de la literatura y prácticas de lectura. La conversación y la escucha en las (con)texturas teórico-críticas y pedagógico-didácticas. Catalejos. Revista sobre lectura, formación de lectores y literatura para niños, 3 (5), 146-169.

Romero, A., Tejada, E. eta Garay, U. (2017). Irakurtzeko gaitasuna Haur Hezkuntzan. Teoriatik praktikara. Tantak, 29(2), 99-118. DOI: http://dx.doi. org/10.1387/tantak.17708

Ruiz, D. eta Bañales, I. (2015). Ibabe, eredu dialogikoa. Solasaldi literarioak eta curricularrak. Arbela, 47, 24-26.

Sainz, L.M. (2005). La importancia del mediador: una experiencia en la formación de lectores. Revista de Educación, número extraordinario, 357-362.

Sancho, E. (2016). Las tertulias literarias dialógicas. Textos de didáctica de la lengua y la literatura, 74, 69-73.

Selfa, M., Fraga, F. eta Berengué, I. (2014) Leer sobre la muerte en la Biblioteca de Aula: una experiencia práctica de lectura en una aula de Educación Infantil. ISLL, 3, 83-95.

Sendak, M. (2009). Piztiak bizi diren lekuan. Pontevedra: Kalandraka.

Tébar, L. (2003). El perfil del profesor mediador. Madril: Santillana. 